E-JURNAL EKONOMI DAN BISNIS UNIVERSITAS UDAYANA
Available online athttps://ojs.unud.ac.id/index.php/EEB/index
Vol. 11 No.02, Februari 2022, pages: 187-196
e-ISSN: 2337-3067

\title{
POLITICAL STABILITY, INDEX PERCEPTION OF CORRUPTION AND DIRECT FOREIGN INVESTMENT IN SOUTHEAST ASIA
}

\begin{tabular}{|c|c|}
\hline \multicolumn{2}{|r|}{ Nairobi $^{1}$ Nur Amalia ${ }^{2}$} \\
\hline Article history: & Abstract \\
\hline $\begin{array}{l}\text { Submitted: } 12 \text { Maret } 2021 \\
\text { Revised: } 23 \text { Maret } 2021 \\
\text { Accepted: } 20 \text { Agustus } 2021\end{array}$ & $\begin{array}{l}\text { The incoming foreign direct investment willbring technology, new } \\
\text { innovations, increase in capital, createjobs that will absorb unemployment, } \\
\text { and improve the quality of human resources so that investment is } \\
\text { considered important in accelerating economic growth in developing } \\
\text { countries. The purpose of this study was to determine the effect of political } \\
\text { stabilityand the Corruption Perception Index on Foreign Direct Investment }\end{array}$ \\
\hline Keywords: & $\begin{array}{l}\text { in Southeast Asia. This study uses secondary data obtained from the World } \\
\text { Bank, and TransparencyInternational. The methodused is a panel data }\end{array}$ \\
\hline $\begin{array}{l}\text { Corruption Perception Index; } \\
\text { Inflation; } \\
\text { Foreign Direct Investment; } \\
\text { Economic Growth; } \\
\text { Political Stability; }\end{array}$ & $\begin{array}{l}\text { model with a total cross-section of } 10 \text { (ten) countries in Southeast Asia and } \\
\text { a time-series in 2010-2019. The researchwas conducted in } 10 \text { countries } \\
\text { due to Timor-Leste because the country officially became a member of } \\
\text { Southeast Asia in 2011. The research method used in this study is the } \\
\text { Random Effect Model. The results showed that the independentvariables of } \\
\text { political stability, corruption perception index (GPA), and economic } \\
\text { growth (EG) each hada significant andpositive effect on foreign direct } \\
\text { investment in Southeast Asia, while inflation andexchange rates had no } \\
\text { effect on foreigndirectinvestment. in Southeast Asia } 2010-2019 \text { period, } \\
\text { ceteris paribus. }\end{array}$ \\
\hline
\end{tabular}

\section{Kata Kunci:}

Indeks Persepsi Korupsi; Inflasi;

Investasi Asing Langsung; Pertumbuhan Ekonomi;

Stabilitas politik;

\section{Corresponding:}

Faculty of Economics and Business, University of Lampung, Lampung, Indonesia Email:nairobi@feb.unila.ac.id

\section{Abstrak}

Investasia sing langsung yang masuk a kan m embawa teknologi, inovasi baru, penambahan modal, menciptakan lapangan kerja yang menyerap pengangguran, dan meningkatkan kualitas sumber daya manusia sehingga investasi dianggap penting dalam memperce pat pertumbuhan ekonomidinega ra berkembang. Tujuan daripenelitian ini a dalah untuk mengetahui pengaruh stabilitas politik dan Indeks Persepsi Korupsi terhadap Penanaman Modal Asing di Asia Tenggara. Penelitian ini menggunakan data sekunder yang diperoleh dari Bank Dunia, dan Transparency International. Metode yang digunakan a da lah model data panel dengan totalcross section 10 (sepuluh) negara di Asia Tengga ra dan time series tahun 2010-2019. Penelitian dilakukan di 10 negara dikarenakan Timor-Leste karena negara tersebut resmi menjadi anggota Asia Tenggara pa da tahun 2011. Metode penelitian yang digunakan dalam penelitia $\mathrm{n}$ in $\mathrm{i}$ adalah Random Effect Model. Hasil penelitian menunjukkan bahwa va ria bel independen stabilita s politik, indeks persepsi korup si (IPK), da n pertumbuhan ekonomi (EG) masing-masing berpengaruh sign if ik an dan positif terhadap investasi asing langsung di Asia Tenggara, sedangkan infla si dan nilai tukar tidak berpengaruh terhadap in vestasi la ngsung a sing. investasi. di Asia Tenggara periode 2010-2019, ceteris paribus.

Faculty of Economics and Business, University of Lampung, Lampung, Indonesia ${ }^{1}$

Email: nur.amalia0920@gmail.com 


\section{INTRODUCTION}

Investment plays an important role in the economy through increased production capacity by forming capital and expanding employment opportunities that encourage an increase in national income. High investment is a source of capital for a country to increase its country's economic growth, on the other hand, a decrease in an investment indicates that reduced state capital formation will slow down economic growth.

Conceptually, economic growth can be increased through investment that is used as a source of capital for a country. This happens because of an increase in the production of goods and services in boosting the economy of a country. However, if the incoming investment is not managed in an unproductive way, it will have an impact on the decline in the country's economic performance, this is due to the production of goods and services which tend to be lower so that economic growth will be low.

Incoming foreign direct investment will bring technology, innovations, increase in capital, create jobs that will absorb unemployment, and improve the quality of human resources so that investment is considered important in accelerating economic growth in developing countries (Febriana \& Muqorobbin, 2014). Frankel (2003) considers that foreign direct investment is better than portfolio investment, this is because the entry of foreign direct investment will be followed by technology transfer, ability in risk and return management.

The development of investment will encourage an increase in capital which will increase the production of goods and services in the country and have an impact on increasing output and economic growth (Shandra et al., 2012). Investors' decisions in investing are influenced by several factors, one of which is the policy established by the government. In the formulation of this policy, it cannot be separated from the role of the political members of the country. Formulated legal and political policies must be able to prosper the community and make it easier for foreign investors to invest (Kok \& Ersoy, 2009).

According to the 2013 World Investment Report, Southeast Asia has become an attractive area as an investment destination, since the economic crisis in 1997-1998. Foreign direct investment entering Southeast Asia has shown rapid development in attracting foreign investor confidence. Vietnam, Indonesia, Thailand, and Malaysia were the countries that were included in the category of top 20 host economies for Foreign Direct Investment from 2010 to 2012. Based on the results of the UNCTAD survey of transnational companies (TNC), during the 2013-2015 period the Southeast Asia region remained the host country for foreign direct investment.

Investors will look for large market potentials that are usually found in developing countries with broad regional categories accompanied by a large population, this will encourage foreign investment inflows. Financial services and high-tech industries become investment targets. Southeast Asia has increased investment in part due to high economic growth. United Nations Conference on Trade and Development (2005) by getting new investors is a motive for increasing production capital. The number of foreign direct investment flows into Southeast Asia is the largest increase in Asia compared to other regions.

According to UNCTAD (2020) countries in the Southeast Asia region are making policy changes that can attract investors to invest. Indonesia introduced 15 years of income tax breaks for foreign companies investing in certain areas. Malaysia allows foreign companies to invest $100 \%$ in brokerage companies and venture capital. Thailand introduces new incentives in pharmaceutical projects. Daewoo Bus Corporation invests in a production facility in Vietnam, and Intel has plans to build the first semi-conductor facility in the country (Anyanwu, 2011). Based on Figure 1, the highest level of political stability occurred in Singapore, followed by Brunei Darussalam, Laos, and Vietna m. Meanwhile, the lowest level of political stability occurred in Myanmar, followed by the Philippines, Thailand, and Indonesia. 


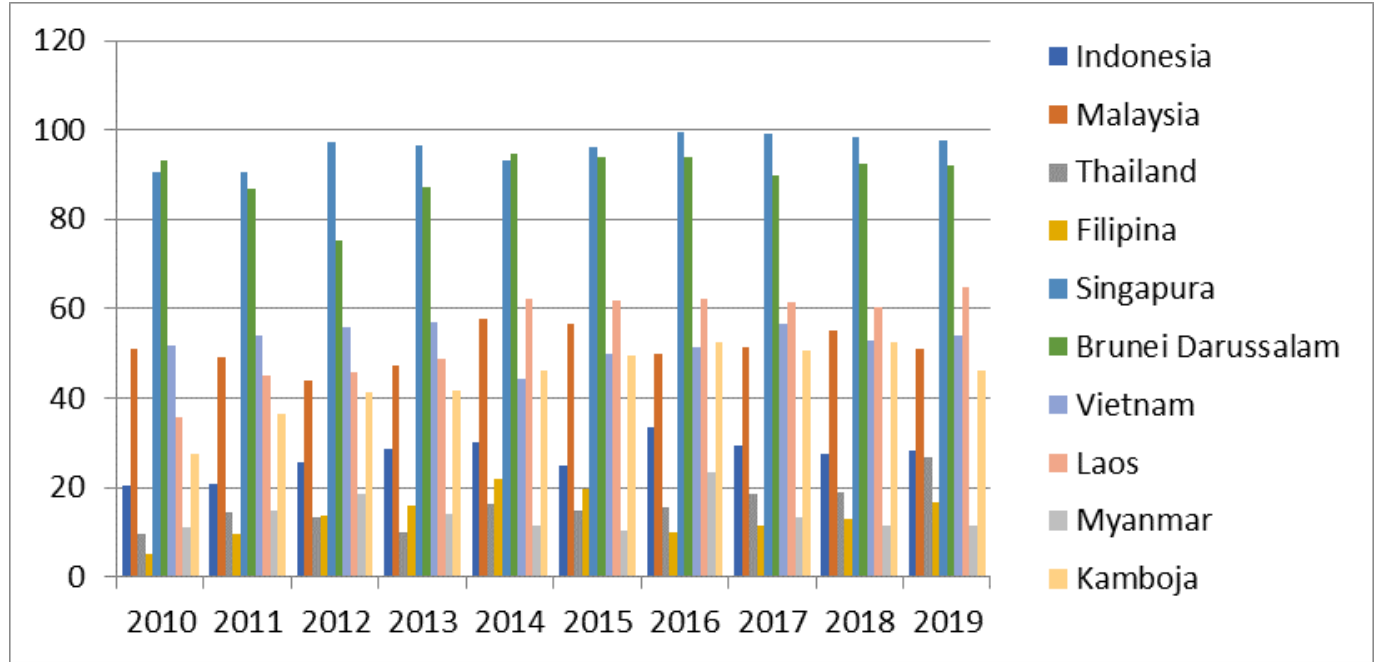

Source: WorldBank, 2020

Figure 1.

Political Stability of Countries in Southeast Asia, 2010 - 2019

Zakariya et al., (2017) states that investors will decide to invest in a country that has stable political conditions and has a clear legal umbrella. Investors do not want to take risks in investing in countries with unstable political and legal conditions. The research was also carried out by Rihab \& Lotfi (2011) who explain that foreign direct investment is not only influenced by economic, which explains that political economy factors, and social conditions, but the quality of the government system, the level of corruption, human resources, and economic openness are the main factors that investors consider in investing.

The existence of corruption will disrupt the transition mechanism of state income and wealth. The level of corruption will reduce the interest of foreign investors to invest, investors do not want to risk losses in investing. Mauro (2004) shows that controlling corruption will encourage the entry of foreign investment and have an impact on increasing economic growth. The low level of corruption will increase government spending on social security and public welfare. Mauro (2004) states that corruption can suppress the entry of foreign direct investment, domestic investment, so that it has an impact on decreasing economic growth.

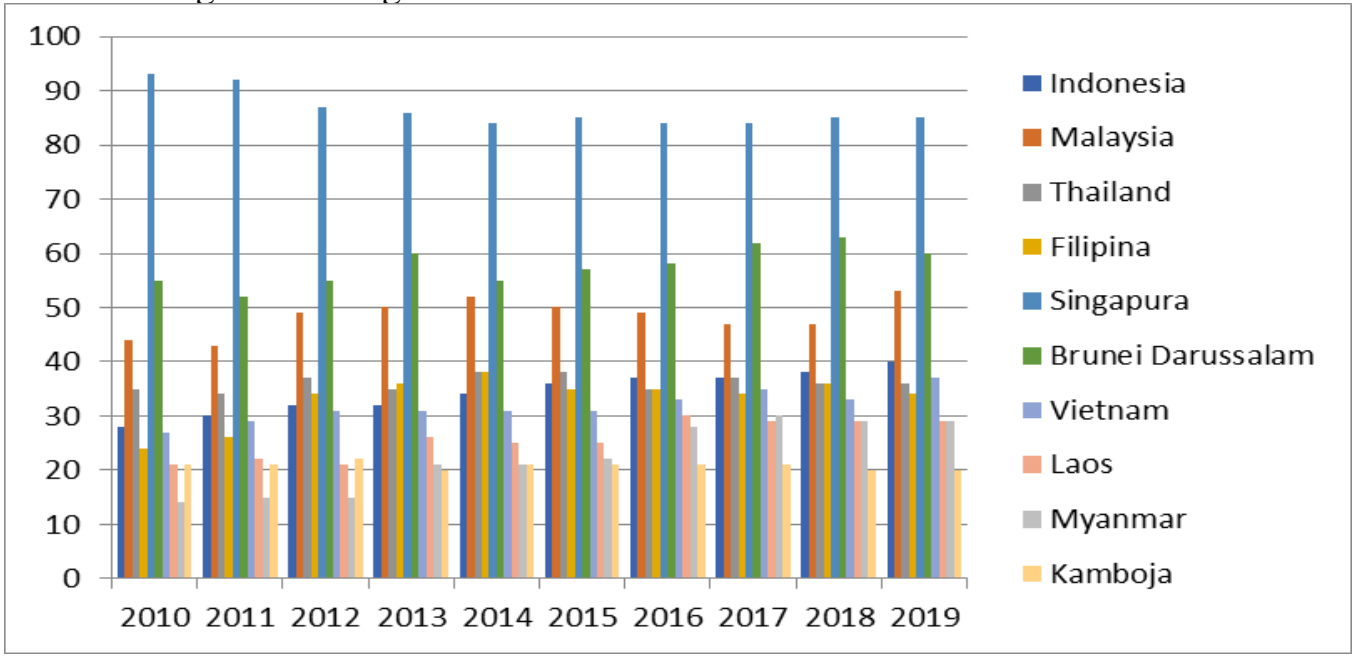

Source: Transparency International, 2020

Figure 2.

Corruption Perception Index of Countries in Southeast Asia for the Period 2010 - 2019

Based on Figure 2 Cambodia has the highest level of corruption, followed by Laos, Myanmar, and the Philippines. Meanwhile, the lowest level of corruption occurred in Singapore, followed by

Political Stability, Index Perception Of Corruption And Direct Foreign Inbestment In Southeast Asia, Noirobi and Nur Amelia 
Brunei Darussalam, Malaysia, and Indonesia. Each country has its policies internally that will influence investors' decisions to invest, investors will choose countries with stable conditions and conducive investment films. There are several indicators to assess the volatility of incoming foreign capital, namely: First, macroeconomics such as GDP, fiscal policy, inflation, interest rates, exchange rates, the balance of payments, etc. Second, the quality of government within the country itself (Yıldırım \& Gökalp, 2016).

Tambunan et al., (2015) mentions several factors that determine the investment climate in a country, not only concerning inefficient government bureaucracy, inadequate infrastructure, policy instability, corruption, low access to finance, and tax regulations but also influenced by economic stability as reflected in stable currency exchange rates, inflation, interest rates, and economic growth. This factor is one of the considerations for foreign and domestic investors in investing.

Inflation is a macroeconomic indicator that investors consider investing. Azam (2010), Anyanwu (2011), Wadhwa \& Reddy S (2011), and Demirhan \& Masca (2008) found that inflation can reduce incoming foreign direct investment statistically. If the general price increase continues, it will have an impact on the decline in people's purchasing power and increase the risk of business failure so that domestic investment becomes less attractive to investors.

Another factor affecting foreign direct investment is the exchange rate, namely the price that must be paid when conducting international transactions. Bouoiyour (2007) and Udoh \& Egwaikhide (2008) found that the exchange rate has a negative and significant effect on foreign direct investment. Omankhanlen (2011) states that when a country's exchange rate depreciates, it will have a positive effect on foreign direct investment because workers' wages and production costs will decrease or be cheaper for foreign investors.

Political stability and corruption are among the factors that influence the entry of foreign investment. The main indicator of legal certainty is determined by the level of corruption. The higher the corruption in a country, the lower the incoming investment. Data on developments in political stability and the Corruption Perception Index in Southeast Asia illustrate that the volatility of the level of foreign capital inflows into Southeast Asian countries is not always in line with the direction of volatility in the value of government quality from several indicators.

The high quality of government is not always accompanied by an increase in foreign direct investment and vice versa. This is a gap phenomenon in this study, where countries with a low level of political stability can attract foreign investors to invest in these countries, such as Indonesia and Myanmar. On the other hand, countries with a high CPI level have a low level of foreign direct investment, as reflected in the countries of Brunei Darussalam and Thailand.

\section{METHOD}

This type of research is descriptive quantitative and the data in this study is secondary data, consisting of data on foreign direct investment, political stability, corruption perception index, economic growth, inflation, and exchange rates from 10 countries in Southeast Asia, namely Indonesia, Malaysia, Thailand, The Philippines, Singapore, Brunei Darussalam, Vietnam, Laos, Myanmar, and Cambodia for the period 2010 - 2019 obtained from the World Bank, Transparency International, as well as sources from online media as references that can support this research.

The dependent variable in this study is a foreign direct investment in Southeast Asia using the ratio of realization of foreign direct investment to GRDP at constant prices in 2010. The independent variables consist of 1) political stability variables obtained from the World Bank, 2) Corruption Perceptions Index obtained from the Transparency International report, 3) economic growth of countries in Southeast Asia obtained from the World Bank, 4) inflation in Southeast Asian countries obtained from the World Bank, and 5) the exchange rates of currencies in Southeast Asia against the United States dollar obtained from World Bank.

The model equation in this study is formed based on the Dunning theory approach and adapted from previous research by Rihab \& Lotfi (2011). 
Foreign Direct Investment Variable $=\mathrm{f}\{$ Economic Variable, Political Variable, Socialite Variable, Cultural Variable

Furthermore, the model is transformed into a model equation in this study:

$\mathrm{FDI}_{\mathrm{it}}=\beta_{0}+\beta_{1} \mathrm{SBP}_{\mathrm{it}}+\beta_{2} \mathrm{IPK}_{\mathrm{it}}+\beta_{3} \mathrm{PE}_{\mathrm{it}}+\beta_{4} \mathrm{INF}_{\mathrm{it}}+\beta_{4} \mathrm{ER}_{\mathrm{it}}+\varepsilon_{\mathrm{it}}$

Where:

$\mathrm{FDI}_{\text {it }} \quad=$ Foreign Direct Investment

$\mathrm{SBP}_{\text {it }} \quad=$ Political Stability

$\mathrm{GPA}_{\mathrm{it}} \quad=$ Corruption Perceptions Index

$\mathrm{EG}_{\mathrm{it}} \quad=$ Economic growth

$\mathrm{INF}_{\text {it }} \quad=$ Inflation

$\mathrm{ER}_{\mathrm{it}} \quad=$ Exchange rate against the United States Dollar

$\beta_{\mathrm{i}} \quad=$ Constants / Intercept

$\varepsilon \quad=$ standard error.

$\mathrm{i} \quad=1,2, \ldots \mathrm{n}$, indicates the number of individuals (cross section)

$\mathrm{t} \quad=1,2, \ldots \mathrm{t}$, denotes the time series (time series)

A panel data method is an analytical tool used in this study using E-Views 9.0. According to Gujarati, \& Porter (2013) the combination of cross-section and time-series data is panel data. Crosssection data is data collected simultaneously from several regions, companies, or individuals. While time-series data is data that is arranged based on time sequences, such as daily, monthly, quarterly or annual data. Combining the two types of data can be seen that the bonded variable yields Sukuk consists of several individual units (cross-section) but in various periods (time series) Baltagi (2015).

Selection of the best model in the panel data method uses 3 methods (Beckett, 1975) as follows the Pooled Least Square regression model is the simplest estimate of panel data testing, which combines cross-section and time-series data. Testing only uses the Ordinary Least Square without paying attention to individual dimensions (cross-section) and time dimensions (time series). The assumption in the approach is that the intercept between the cross-section dimensions is different but the slope of the time series dimensions remains the same. To estimate the fixed effect model is to use the dummy variable technique method to explain the differences in the intercept. This estimation model is often called the Least Square Dummy Variables (LSDV) technique. to represent ignorance of the actual model that is the purpose of including the dummy variable in the fixed effect model. However, this also leads to a decrease in the degrees of freedom which ultimately reduces the efficiency of the parameters. This problem can be solved using an error term known as the Random Effects Model method.

To determine the best model that can be used in analyzing and predicting three stages of testing, namely the Chow test, this test is carried out to select the best model between PLS and FEM, the Hausman test, this test is carried out to choose the best model between FEM and REM, and the LM test. to choose the best model between PLS and REM (Beckett, 1975).

The classical assumption test that is carried out is the normality test which has the aim of detecting whether the data used is normally distributed with the criteria if the probability value is greater than 0.05 or 5\% (Gujarati \& Porter, 2009). The multicollinearity test is detection that shows whether the regression model data used has a relationship between independent variables. multicollinearity detection can use the rule of thumb 0.80 with the criterion value obtained is not more than 0.80 , so it can be concluded that there is a multicollinearity disorder (Widarjono, 2018). The heteroscedasticity test aims to detect irregularities in the homoscedasticity assumption that is not constant. The regression results will show misleading if the regression model is exposed to heteroscedasticity problems (Gujarati \& Porter (2013). A heteroscedasticity test was done by comparing Obs * R-Squared with $\chi^{2}$ (Chi-Square) table. If the Obs * R-Squared value is greater than 
$\chi 2$ table, then there is no heteroscedasticity in the model. The autocorrelation test aims to detect whether there is a relationship between confounders or residuals in the regression model using detection using the Breusch-Godfrey Serial correlation LM Test by comparing the Obs * R Square value with the Chi-square value (Gujarati \& Porter, 2009).

The t-test is used to see the partial significance of the influence of the independent variables on the dependent variable at a significance of $\alpha=5$ percent ceteris paribus. In this case, the value between $\mathrm{t}$-count and t table with the test criteria if $\mathrm{t}$ table> $\mathrm{t}$ statistic, then $\mathrm{H}_{0}$ is accepted, $\mathrm{Ha}$ is rejected. This means that partially the independent variable regression coefficient has no significant effect on the dependent variable and vice versa. The statistical $F$ test is used to determine the effect of all independent variables on the dependent variable simultaneously or together. The test criteria if $F$ table> F statistic, then $\mathrm{HO}$ is accepted $\mathrm{Ha}$ rejected. This means that the regression coefficient of the independent variables together does not have a significant effect on the independent variables and vice versa. The coefficient of determination test is carried out to see how much influence the independent variable has on the dependent variable used in the study. If the value of $\mathrm{R} 2$ is close to 1 , the independent variable used can properly explain the variation of the dependent variable.

\section{RESULTS AND DISCUSSION}

Table 1.

Results of Panel Data Regression for Bound Variables of Foreign Direct Investment

\begin{tabular}{cccc}
\hline Variable & CEM & FEM & REM \\
\hline Constant & 3,1755 & 5,5963 & 8,9986 \\
PoliticalStability & $(0,2403)$ & $(0,0351) *$ & $(0,0000)^{*}$ \\
(SBP) & 0,0504 & 0,0260 & 0,1082 \\
Corruption Perceptions Index & $(0,1287)$ & $(0,4837)$ & $(0,0001)^{*}$ \\
(GPA) & 0,0424 & 0,0215 & 0,1268 \\
Economic growth & $(0,3919)$ & $(0,7353)$ & $(0,0020)^{*}$ \\
(PE) & 0,0245 & $-0,0148$ & 1,0231 \\
Inflation & $(0,8191)$ & $(0,8916)$ & $(0,0000)^{*}$ \\
(INF) & $-0,1484$ & $-0,1735$ & 0,0810 \\
Exchange rate & $(0,0932) * *$ & $(0,0577) * *$ & $(0,6793)$ \\
(ER) & $-0,0001$ & $-0,0001$ & 0,00007 \\
Chow test & $(0,5278)$ & $(0,6061)$ & $(0,3517)$ \\
\hline Hausman Test & & 56,9208 & \\
Exams Lagrange Multiplier(LM) & & $(0,0000) *$ & $(0,1410)$ \\
\hline
\end{tabular}

Source: Eviews 9.0 Output, 2021

Information: $*$ ) significa nt at $\alpha=5 \%$ and $* *$ ) significant at $\alpha=10 \%$

The Chow test is a test conducted to select the best approach model between the Common Effect Model and the Fixed Effect Model by looking at the value of the F statistical distribution. If the probability value of the $\mathrm{F}$ statistical distribution is more than the specified significance level value, the model used is the Common Effect Model and if the probability value of the F statistical distribution is less than the significance level, the model used is the Fixed Effect Model (Gujarati \& Porter, 2009).

Tabel 2.

\section{Chow Test Result}

\begin{tabular}{ccc}
\hline Effects Test & Statistic & d.f. \\
\hline Political Stability, Index Perception Of Corruption AndDirect Foreign Inbestment In Southeast Asia,
\end{tabular}




\begin{tabular}{cccc}
\hline Cross-sectionF & 56,9208 & $(9,85)$ & 0,0000 \\
\hline
\end{tabular}

Source: Eviews 9.0 Output, 2021

The Prob. Cross-section F of 0,0000 is smaller than the real level $(\alpha)$ of 5 percent, $(0,0000<$ $0,05)$ then $\mathrm{H} 0$ is rejected and accepts $\mathrm{Ha}$, so it can be concluded that the Fixed Effect Model (FEM) method is better than the method. Common Effect Model (CEM) to analyze the data in this study. The Hausman test is a test conducted to compare and choose between the Random Effect (REM) and the Fixed Effect (FEM). This test uses the Chi-Squares value in determining the best model to use in a study.

Table 3.

Hausman Test Results

\begin{tabular}{cccc}
\hline Test Summary & Chi-Sq. Statistic & Chi-Sq. d.f. & Prob. \\
\hline Cross-section random & 8,2892 & 5 & 0,1410 \\
\hline Source:
\end{tabular}

Source: Eviews 9.0 Output, 2021

The p-value of 0,1410 is biger than the $\alpha$ significance level of $5 \%(0,05)$, it can be concluded that the Random Effect Model (REM) method is better used than the Fixed Effect Model (FEM) method in this study.

The Breusch-Pagan Lagrange Multiplier (LM) test was conducted to select the best method between Common Effect (CEM) and Random Effect (REM). Drawing conclusions from the test results by looking at the value of the Breusch-Pagan Cross-section. If the Breusch-Pagan Cross-section value is smaller than the real level $(\alpha)$, the Random Effect (REM) method is better, and vice versa if the Breusch-Pagan Cross-section value is greater than the real level $(\alpha)$ then the Common Effect (CEM) method better.

Table 4.

Hasil LM-Test

\begin{tabular}{cccc}
\hline & Test Hypothesis & & \\
\hline & Cross-section & Time & Both \\
\hline \multirow{2}{*}{ Breusch-Pagan } & 186,7981 & 2,8393 & 189,6374 \\
& $(0,0000)$ & $(0,0920)$ & $(0,0000)$ \\
\hline
\end{tabular}

Source: Eviews 9.0 Output, 2021

The Breusch-Pagan BP probability value of 0,0000 is smaller than the 5\% significance level, indicating that the probability value ( $\mathrm{p}$-value) $<0,05$ means that the Random Effect (REM) method is better than the Common Effect (CEM) method. to analyze the data in this study.

Based on the results of the Chow Test which resulted in the Fixed Effect Model (FEM) being better than the Common Effect Model (CEM) and the Hausman Test results which resulted in the Fixed Effect Model (FEM) being better than the Random Effect Model (REM). while the LM Test results show that the Random Effect Model is better than the Common Effect Model. Then the Random Effect Model (REM) is best to use in this study. Based on the probability value of 0,1094 which is greater than $\alpha(0,05)$, it can be concluded that the data is normally distributed.

Table 5.

Partial Correlation Test Results

\begin{tabular}{cccccc}
\hline Variable & SBP & GPA & PE & INF & ER \\
\hline SBP & 1,0000 & 0,7360 & $-0,3601$ & $-0,3642$ & $-0,0189$ \\
GPA & 0,7360 & 1,0000 & $-0,4101$ & $-0,4148$ & $-0,3225$ \\
PE & $-0,3601$ & $-0,4101$ & 1,0000 & 0,3976 & 0,2438 \\
INF & $-0,3642$ & $-0,4148$ & 0,3976 & 1,0000 & 0,4199 \\
ER & $-0,0189$ & $-0,3225$ & 0,2438 & 0,4199 & 1,0000 \\
\hline
\end{tabular}

Source:Processed Eviews 9.0,2021 
From the multicollinearity that has been produced that there are no variables that have a value of more than 0.85 , it can be concluded that there is no multicollinearity.

Table 6.

Heteroscedasticity Test Result

\begin{tabular}{cccc}
\hline Dependent Variable & Chi Square Statistic & Chi Square Table & Conclusion \\
\hline 1 & 1,5042 & 11,07 & Homoskedasticity \\
\hline Source: Procesed
\end{tabular}

Source: Processed Eviews 9.0,2021

Based on the calculated Chi-Square value of $(1,5042)$ smaller than the Chi-Square Table $(11,07)$, heteroscedasticity does not occur.

Table 8.

Autocorrelation Test Result

\begin{tabular}{cccc}
\hline Dependent Variable & Chi Square Statistic & Chi Square Table & Conclusion \\
\hline 1 & 1,0332 & 5,99 & Autocorrelation \\
\hline Source Processed Eviews 90,2021 & &
\end{tabular}

Source: Processed Eviews 9.0,2021

Based on the calculated Chi-Square value $(1,0332)$ is smaller than the Chi-Square Table $(5,99)$, then there is no autocorrelation. Based on the research results, political stability has a significant a nd positive effect on foreign direct investment. Political stability is related to the perceptions of investors. If investors feel insecure, their ex pectations of investing will decrease. Such decline in inve st or confidence will ha ve an impact on reducing investment to be channeled. Political instability will reduce investor interest. Musila \& Sigué (2006), Dash \& Raja (2009), and Bissoon (2012) argues that the level of political stability has a significant and positive effect on foreign direct investment, where political instability in a country will reduce the interest of foreign investors to invest in the country concerned.

Based on the results of the study, an increase in foreign direct investment can be done by increasing the perception index of corruption. There are two views on corruption, namely corruption will be considered as a lubricant for the economy if the eradication of corruption is increased in a country. On the other hand, corruption will suppress and endanger the economy (sand wheels). The problem of corruption is a problem that really needs to be considered because corruption can hinder the entry of investment which is a source of economic capital for expansion. if corruption control can be carried out, it can make positive changes to the country's productivity, macro economy, investment and human resources in a country.

Based on the research results, economic growth has a significant and positive effect on foreign direct investment. Economic growth shown by gross domestic product (GDP) is the same as national income in a country. With a high level of national income that will affect people's income, then the high people's income will increase the demand for goods and services. Then the company's profits will increase and this will encourage more investment to enter a country. Zenasni \& Benhabib (2013), Udoh \& Egwaikhide (2008), Eliza \& Ismail (2013), Sikwila (2014), and Tambunan et al. (2015) positive economic growth will increase incoming foreign direct investment.

Based on research results, inflation and exchange rates do not have a significant effect on foreign direct investment. Omankhanlen (2011), Ahmed E. \& Gabriel (2012), and Gharaibeh (2015) found that inflation has no significant effect on the flow of foreign direct investment into a country. Meanwhile, Ahmed \& Gabriel (2012) found that the exchange rate has no significant effect on the entry of foreign direct investment.

\section{CONCLUSIONS}

The results show that political stability, Corruption Perception Index, and economic growth can encourage an increase in foreign capital inflows, while inflation and the exchange rate had no 
significant effect on foreign direct investment. For this reason, governments in the Southeast Asian region should further improve and maintain political stability by being more careful in making policies, rules of law, and making decisions that can trigger political shocks such as anti-government demonstrations, demonstrations against cabinet changes, and constitutional changes, revolution, riots, coups, wars, and so on.

\section{REFERENCE}

Ahmed E., U., \& Gabriel, A. M. (2012). The Determinants a nd Impacts of Foreign Direct Investment in Nigeria . International Journal of Business and Management, 7(24). 67-77 https://doi.org/10.5539/ijbm.v7n24p67

Anyanwu, J.C. (2011). Determinants of Foreign Direct Investment Inflows to Africa, 1980-2007. Working PaperSeries, 136(1), 1-31.https://doi.org/10.47260/bae/812

Azam, M. (2010). Economic Determinants of Foreign Direct Investment in Armenia , Kyrgy z Republic and Turkmenistan : Theory and Evidence. Eurasian Journal of Business and Economics, 3(6), 27-40.

Baltagi, B. H. (2005). Econometric Analysis of Panel Data. In John Wiley \& Sons Ltd (3thed.). John Wiley \& Sons Ltd.https://doi.org/10.3109/00498257509056115

Baltagi, B. H. (2015). Panel Data. Oxford University Press.

Bissoon, O. (2012). Can better institutions attract more Foreign Direct Investment (FDI)? Evidence from developing countries. International Research Joumal of Finance and Economics, 82, 142-158.

Bouoiyour, J. (2007). The determining factors of foreign direct investment in Morocco. Savings and Development, 31(1), 91-106.

Dash, B. B., \& Raja, A. V. (2009). Institutions and the quality of governance: An empirical study on in terstate differences in economic development in India. Asia-Pacific Development Journal, 16(1), 1-26. https://doi.org/10.18356/ba16484f-en

Demirhan, E., \& Masca, M. (2008). Determinants of foreign direct investment flows to developing countrie s: A cross-sectional analysis. Prague Economic Papers, 4, 356-369. https://doi.org/10.18267/j.pep.337

Eliza, M., \& Ismail, M. (2013). Analisis Pengaruh Variabel Makroekonomi Terhadap Investasi Asin g. Jurnal Ilmiah Mahasiswa FEB Universitas Brawijaya, 1(2). 1-20.

Febriana, A., \& Muqorobbin, M. (2014). Investasi Asing Langsung Di Indonesia Dan Faktor Yang Mempengaruhinya. Jurnal Akuntansi Dan Keuangan, 15(2), 109-117. https://doi.org/10.9744/jak.4.1.pp.17-35

Frankel, J. A. (2003). The Environment and Globalization. Working Paper 10090, 1-39. http://www.nber.org/papers/w10090.pdf

Gharaibeh, A. M. O. (2015). Determinants of Foreign Direct Investment: Empirical evidence from India. International Journal of Business and Social Science, 6(8), 94-106. https://doi.org/10.1956/jge.v10i1.312

Gujarati, D. N., \& Porter, D. . (2009). Single-equation regression models. In Introductory Econometrics: A Practical Approach (5th ed.). Douglas Reiner.

Kok, R., \& Ersoy, B. A. (2009). Analy ses of FDI determinants in developing countries. International Journal of SocialEconomics, 36(1-2), 105-123. https://doi.org/10.1108/03068290910921226

Ma uro, P. (2004). The persistence of corruption and slow economic growth. IMF Staff Papers, 51(1), 1-18. https://doi.org/10.5089/9781451874952.001

Musila, J. W., \& Sigué, S. P. (2006). Accelerating foreign direct investment flow to Africa: from policy statements to successful strategies. Managerial Finance, 32(7), 577-593. https://doi.org/10.1108/03074350610671575

Omankhanlen, A. E. (2011). The Effect of Exchange Rate and Inflation on Foreign Direct Investment a nd Its Relationship with Economic Growth in Nigeria . Economics and Applied Informatics, 1(1). 5-16.

Rihab, B. A., \& Lotfi, B. J. (2011). The institutional and cultural determinants of foreign direct in ve stment in transition countries. Journal of Research in International Business and Management, 1(2), 171-182.

Shandra, Y., Amar, S., \& Aimon, H. (2012). Konsumsi Dan Investasi Serta Pertumbuhan Ek on omi Sumatera Barat. Jurnal Kajian Ekonomi, 1(1), 113-139.

Sikwila, M. N. (2014). Foreign Direct Investment: Does it Matter? A for Zimbabwe. Research in Business and Economics Journal, 10,1-12. https://opendocs.ids.ac.uk/opendocs/ds2/stream/?\#/documents/8892/page/2

Ta mbunan, R. S., Yusuf, Y., \& Mayes, A. (2015). Pengaruh Kurs, Inflasi, Libor da n PDB te rh adap Foreign Direct Investment (FDI) di Indonesia. JOM FEKON, 2(1), 1-16.

Udoh, E., \& Egwaikhide, F. (2008). Exchange Rate Volatility, Inflation Uncertainty and Foreign Direct Investment in Nigeria. Botswana Journal of Economics, 5(7), 14-31.

$$
\text { Political Stability, Index Perception Of Corruption And Direct Foreign Inbestment In Southeast Asia, }
$$


https://doi.org/10.4314/boje.v5i7.60304

Wa dhwa, K., \& Reddy S, S. (2011). Foreign Direct Investment into Developing Asian Countries: The R ole of Market Seeking, Resource Seeking a nd Efficiency Seeking Factors. International Journal of Business and Management, 6(11), 219-226. https://doi.org/10.5539/ijbm.v6n 11p219

Y1ldırım, A., \& Gökalp, M.F. (2016). Institutions andEconomic Performance: AReview on the Developing Countries. Procedia Economics and Finance, 38, 347-359. https://doi.org/10.1016/s2212-5671(16)302076

Zakariya,H., Anjani, R. F., Santosa, H., \& Ganta, F. D. M. (2017). Pengaruh Hukum dan Politik terhadap Perkembangan Investasi Asing di Indonesia. Jurnal Serambi Hukum, 10(02), 69-90.

Zena sni, S., \& Benhabib, A. (2013). The Determinants of Foreign Direct Inv estment and Their Impact on Growth: Panel Data Analysis for AMU Countries. International Journal of Innovation and Applied Studies, 2. 